Vol. 1 No. 1, Feb 2021, hlm. 61 - 70

DOI: https://doi.org/10.33330/.v1i1.1040

Available online at https://jurnal.stmikroyal.ac.id/index.php/jutsi

\title{
RANCANG BANGUN SISTEM INFORMASI PEMETAAN PERSEBARAN MENARA TELEKOMUNIKASI SELULER BERBASIS GIS DI LOMBOK TENGAH
}

\author{
M. Arif Setiawan', Ahmad Tantoni ${ }^{2 *}$, Hairul Fahmi ${ }^{2}$ \\ ${ }^{1}$ Mahasiswa Prodi Teknik Informatika, STMIK Lombok \\ ${ }^{2}$ Prodi Teknik Informatika, STMIKLombok \\ *email:ahmad.tantoni@students.amikom.ac.id
}

\begin{abstract}
Central Lombok Diskominfo availability of very limited information about towers that have not paid or that have already paid fees causes Central Lombok Dikominfo tends not to have accurate and relevant information so it must check the tower. The research objective is to map 320 towers spread across the Lombok Regency in the form of a Google map. The system development method in this study uses XP (Extreme Programming) and the application testing technique uses the Black-Box Testing method. The results of this study are to make it easier for employees / staff in finding the location of the tower that has not paid and who have paid fees by clicking the tower icon in the application.
\end{abstract}

Keywords:Geographic Information Systems, XP (Extreme Programming), Central Lombok

\begin{abstract}
Abstrak:Diskominfo Lombok Tengah ketersediaan informasi yang sangat terbatas mengenai menara yang belum membayar atau yang sudah membayar retribusi menyebabkan Dikominfo Lombok Tengah cenderung tidak memiliki informasi yang akurat dan relevan sehingga harus mengecek menara tersebut.Tujuan penelitian untuk memetakan 320 menara yang tersebar di wilayah Lombok bentuk google map. Metode pengembangan sistem dalam penelitian ini menggunakan XP (Extreme Programming) dan teknik pengujian aplikasi ini menggunakan metode Black-Box Testing.Hasil penelitian ini ialah memberikan kemudahan kepada pegawai/staff dalam mencari lokasi menara yang belum membayar dan yang sudah membayar retribusi dengan cara mengklik icon menara pada aplikasi.
\end{abstract}

Kata kunci:Sistem Informasi Geografis, XP (Extreme Programming), Lombok Tengah

\section{PENDAHULUAN}

Dinas Komunikasi dan Informatika (DISKOMINFO) merupakan suatu instansi yang berada di Lombok Tengah dan bergerak dibidang teknologi dan informasi. Dinas Komunikasi dan Informatika (DISKOMINFO) memiliki peran penting dalam dunia perkantoran dikarenakan menangani masalah menara telekomunikasi yang dimana masyarakat membutuhkan komunikasi untuk bersosialisasi, berinteraksi dan lainnya.

Selama ini proses pendataan menara masih dilakukan dengan cara menempelkan sticker retribusi ke setiap menara dikarenakan adanya menara yang belum membayar retribusi kepada pemerintah dan membangun menara tanpa adanya rekomendasi atau 
Vol. 1 No. 1, Feb 2021, hlm. 61 - 70

DOI: https://doi.org/10.33330/.v1i1.1040

Available online at https://jurnal.stmikroyal.ac.id/index.php/jutsi

persetujuan dari pemerintah atau penanggung jawab untuk daerah kabupaten.Dinas Komunikasi dan Informatika (DISKOMINFO) Kab. Lombok Tengah, melalui proses interview didapatkan permasalahan yang ada di Kabag KOMINFO (Kepala Bagian Komunikasi dan Informatika). Dimana dalam pendataan menara telekomunikasi masih ada yang terdapat tidak ada rekomendasi dari pemerintah kabupaten yang bertanggung jawab dalam pembangunan menara telekomunikasi yang bersebaran di wilayah Lombok Tengah.

Pengertian sistem perpendapat sekelompok elemen-elemen yang terintegrasi dengan tujuan yang sama untuk mencapai tujuan. Organisasi terdiri dari sejumlah sumber daya manusia, material, mesin, uang, dan informasi. Sumber daya tersebut bekerja sama menuju tercapainya suatu tujuan tertentu yang ditentukan oleh pemilik atau menejemen. informasi adalah data yang sudah diolah menjadi bentuk lebih berguna dan berarti bagi yang membutuhkannya.Informasi disebut data yang memiliki arti. Informasi adalah data yang sudah diproses dengan sedemikian rupa sehingga bisa meningkatkan pengetahuan individu / kelompok yang menggunakan.Informasi dapat juga berupa data mentah, data tersusun dan sebagainya [1]. XP (Extreme Programming) merupakan metode pengembangan software berdasarkan nilai-nilai kesederhanaan, komunikasi, umpan balik, keberanian, dan rasa saling menghormati [2].

GIS sebagai alat bantu yang menarik yang dirancang secara interaktif dengan mengintegrasikan data spasial dan atribut yang lainnya. Dengan perkembangan teknologi dan kemajuan teknologi internet serta teknologi informasi maka kemudahan GIS semakin dapat dinikmati oleh masyarakat luas melalui jaringan internet dengan menggunakan webbrowser [3]. Pada umumnya aplikasi GIS dapat diterapkan pada berbagai bidang, seperti bidang utilitas, kesehatan, telekomunikasi, transportasi dan sebagainya [4].

GIS terdiri dari tiga bagian yang terintegrasi, Geografi dunia nyata, atau realita spasial, informasi meliputi arti dan kegunaannya, dan Sistem teknologi komputer dan fasilitas pendukung [5].

Sistem informasi yang dikembangkan oleh peneliti akan memberikan akses control sesuai dengan kebutuhan, admin juga akan memberikan akses user kepada Provider atau pemilik menara agar bisa mengecek informasi-informasi yang berkaitan dengan menaranya. Admin bisa menyampaikan langsung informasi data menara yang tersebar diwilayah kepada semua instansi atau perusahaan telekomunikasi tentang kelengkapan menaranya dan Provider atau pemilik menara bisa mengecek kapan pembayaran retribusi akan jatuh tempo, kapan pembayaran retribusi sudah dilunasi. Provider atau pemilik menara bisa mengaksesnya lewat email dan smartphone.

Merumuskan penenlitian merupakan bagaimana membuat sistem informasi pemetaan persebaran menara telekomunikasi seluler berbasis web GIS (Geographic Information System) di wilayah Kabupaten Lombok Tengah.

\section{METODE}

Metode pertama yang digunakan adalah observasi yang dilakukan adalah pengamatan yang dilakukan secara langsung pada Bagian KOMINFO Kab. Lombok Tengah dengan melakukan wawancara (interview) dan studi pustaka. Wawancara 
Vol. 1 No. 1, Feb 2021, hlm. 61 - 70

DOI: https://doi.org/10.33330/.v1i1.1040

Available online at https://jurnal.stmikroyal.ac.id/index.php/jutsi

merupakan metode yang dilakukan dengan tanya jawab langsung dengan nara sumber yaitu pak Anas Pujiantadi selaku Kasi Bidang KOMINFO Kab. Lombok Tengah pembahasan yang bersangkutan dengan pendataan menara telekomunikasi pada Bagian KOMINFO Kab. Lombok Tengah. Studi pustaka yang dilakukan dengan cara mempelajari teori-teori dari buku, jurnal, dan internet yang berhubungan dengan tema penelitian yang dilakukan oleh penulis.

Rancangan flowmap usulan pendataan menara dapat dilihat pada gambar 1 .

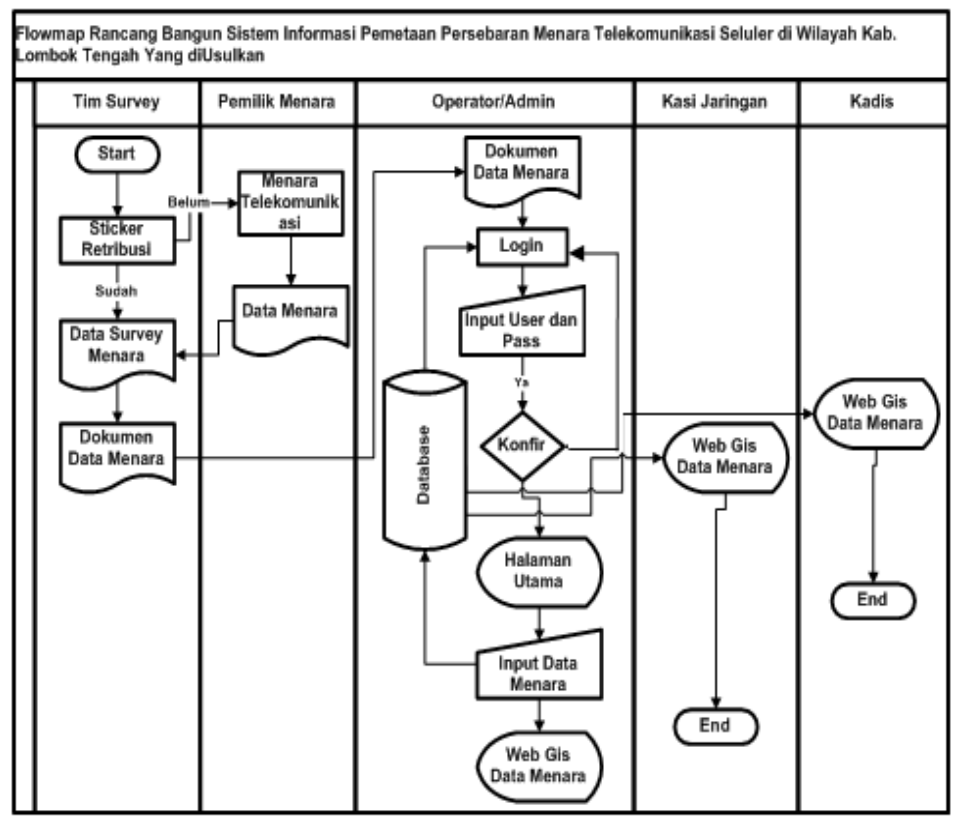

Gambar 1. Flowmap Usulan Pendataan Menara

Use case Diagram sistem informasi berbasis Web GIS diwilayah Lombok Tengah yang diusulkan dapat dilihat pada gambar 2 .

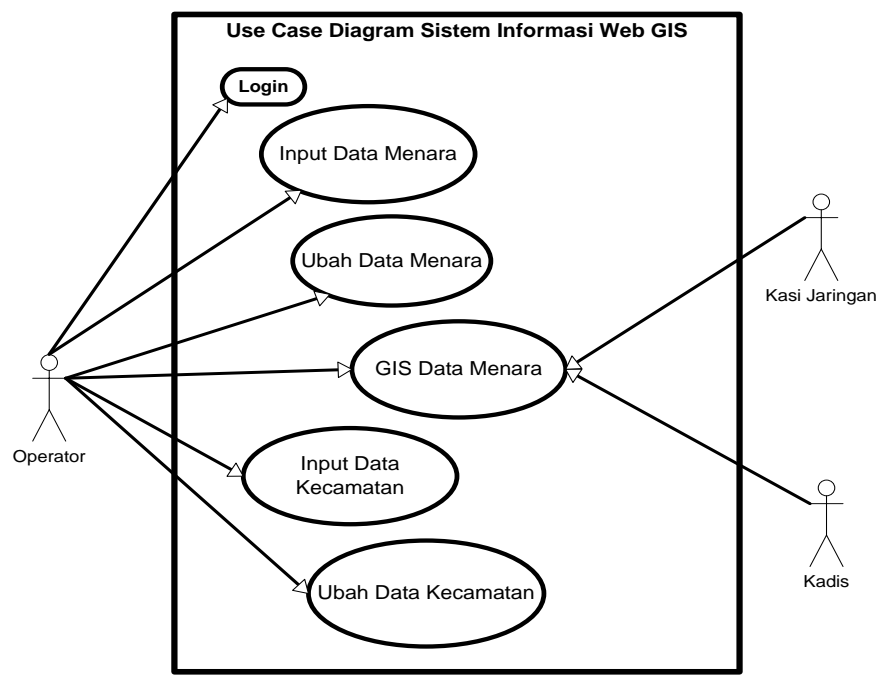

Gambar 2.Use Case Diagram 
Vol. 1 No. 1, Feb 2021, hlm. 61 - 70

DOI: https://doi.org/10.33330/.v1i1.1040

Available online at https://jurnal.stmikroyal.ac.id/index.php/jutsi

Pada activity diagram login admin menggambarkan rangkaian aktivitas login yang dilakukan oleh operator, mulai dari proses login masuk ke sistem halaman utama dapat dilihat pada gambar 3 .

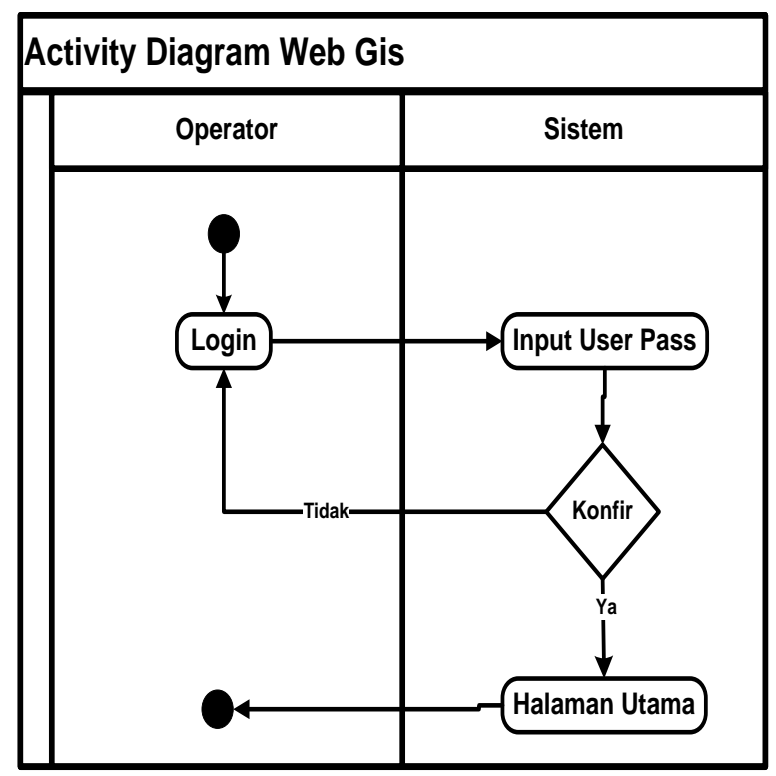

Gambar 3.Activity Diagram Login Admin

Pada activity diagram input data menara menggambarkan rangkaian aktivitas admin yang dilakukan oleh admin, mulai dari proses masuk ke halaman utama dan menambah data menara yang sehingga tersimpan ke dalam database dapat dilihat pada gambar 4.

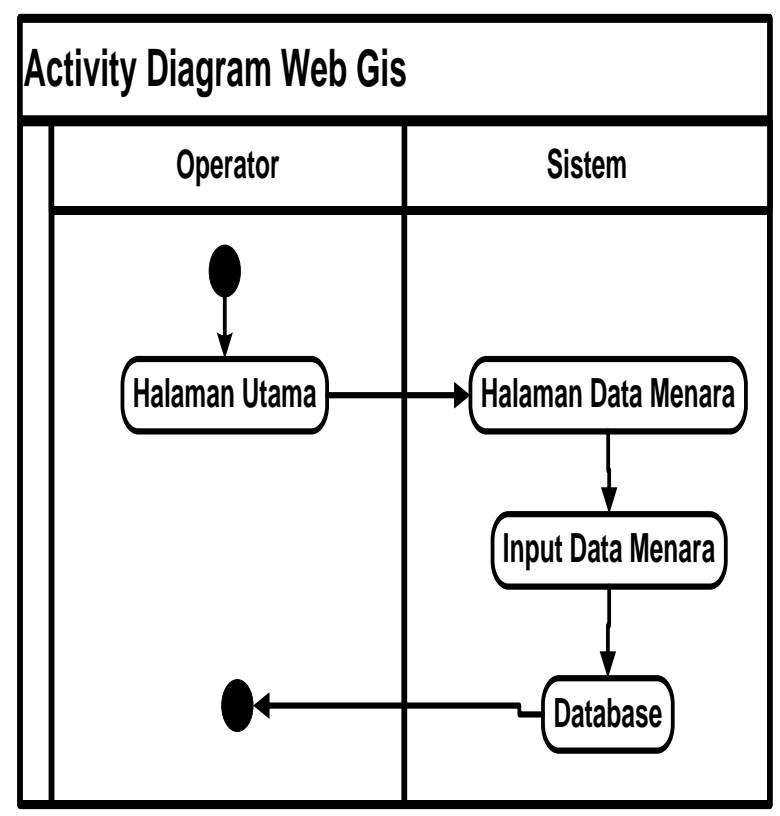

Gambar 4.Acivity Diagram Input Data Menara 
Vol. 1 No. 1, Feb 2021, hlm. 61 - 70

DOI: https://doi.org/10.33330/.v1i1.1040

Available online at https://jurnal.stmikroyal.ac.id/index.php/jutsi

Pada activity diagram input data kecamatan menggambarkan rangkaian aktivitas admin yang melakukan penambahan data kecamatan yang dilakukan oleh admin, mulai dari proses masuk kehalaman utama dan menambah data kecamatan yang sehingga tersimpan ke dalam database dapat dilihat pada gambar 5.

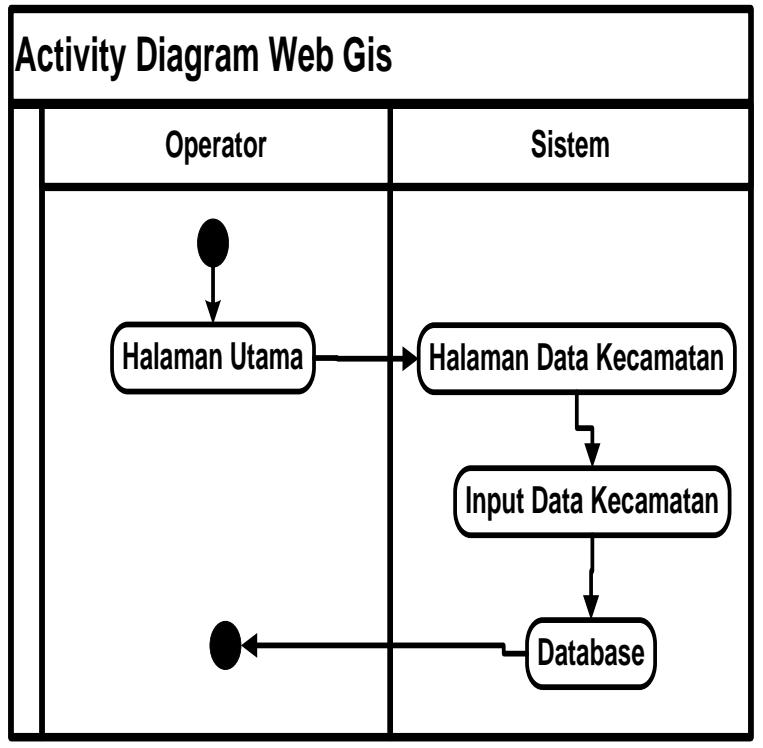

Gambar 5.Activity Diagram Input Data Kecamatan

Pada sequence diagram login menjelaskan tentang rangkaian proses pengolahan data user yang dilakukan oleh user sebagai actor dapat dilihat pada gambar 6 .

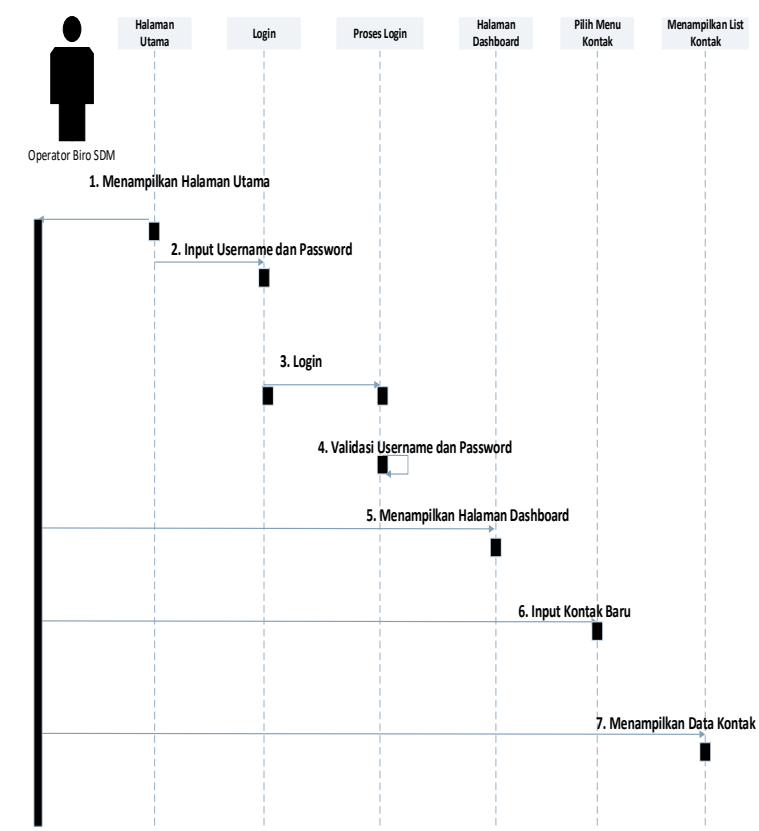

Gambar 6.Sequence Diagram Login 
Vol. 1 No. 1, Feb 2021, hlm. 61 - 70

DOI: https://doi.org/10.33330/.v1i1.1040

Available online at https://jurnal.stmikroyal.ac.id/index.php/jutsi

Pada sequence diagram input data kontakdapat dilihat pada gambar 7.

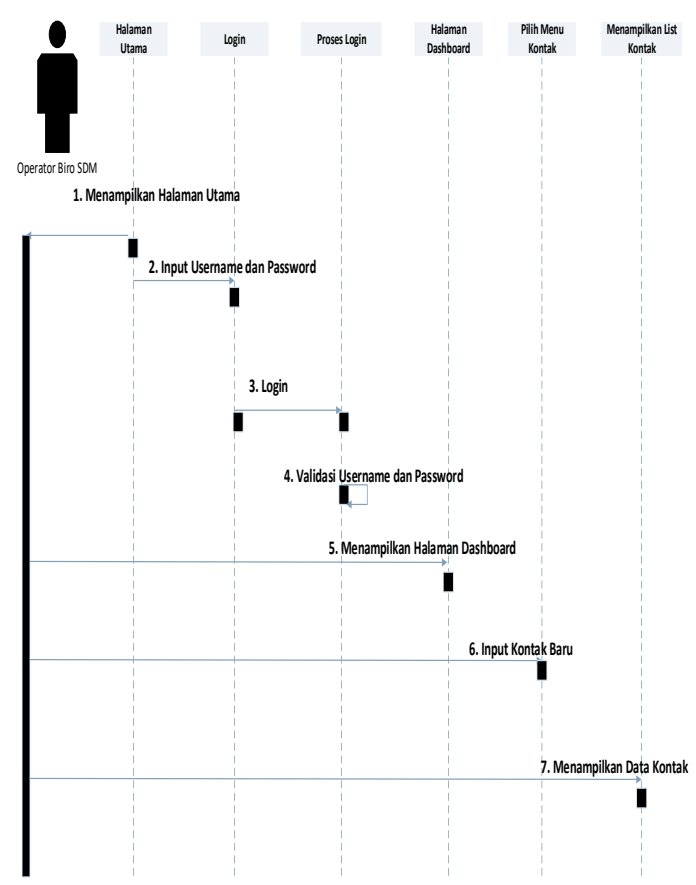

Gambar 7.Sequence Diagram Input Data Kontak

\section{HASIL DAN PEMBAHASAN}

Hasil tampilan halaman utama merupakan halaman yang terlihat saat pertama kali user mengakses, dapat dilihat pada gambar 8 .

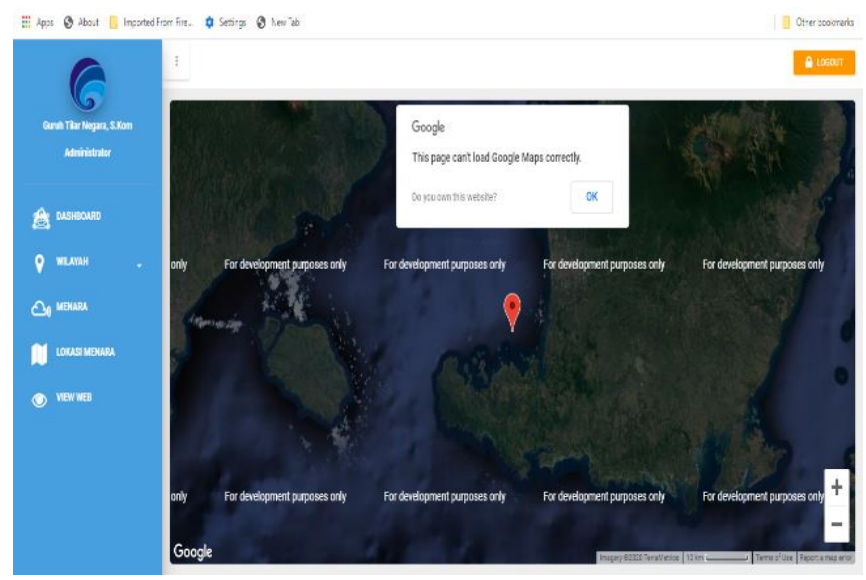

Gambar 8. Halaman Utama

Hasil tampilan halaman login merupakan tampilan pengaman bagi user, jika user yang ingin masuk ke sistem harus memasukkan username dan password yang benar terlebih dahulu,dapat dilihat pada gambar 9. 
Vol. 1 No. 1, Feb 2021, hlm. 61 - 70

DOI: https://doi.org/10.33330/.v1i1.1040

Available online at https://jurnal.stmikroyal.ac.id/index.php/jutsi

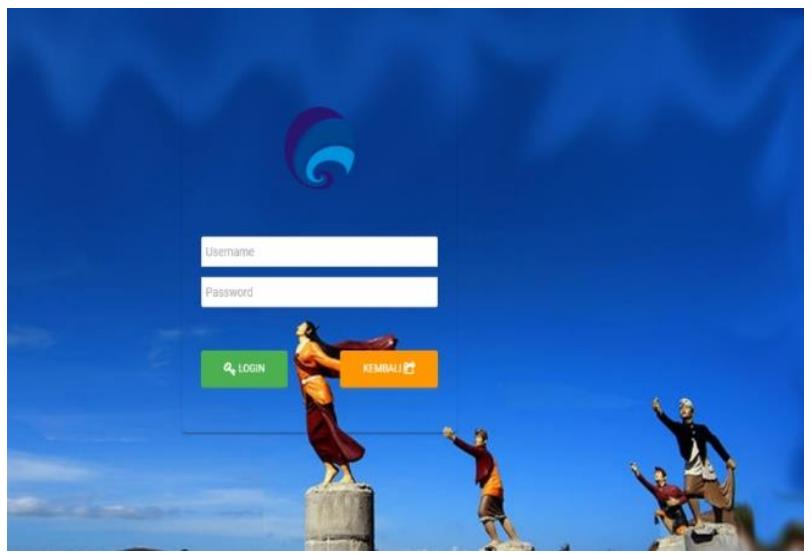

Gambar 9. Halaman Login

Hasil tampilan halaman dashboard ini akan tampil apabila user memasukkan username dan password dengan benar dapat dilihat pada gambar 10 .

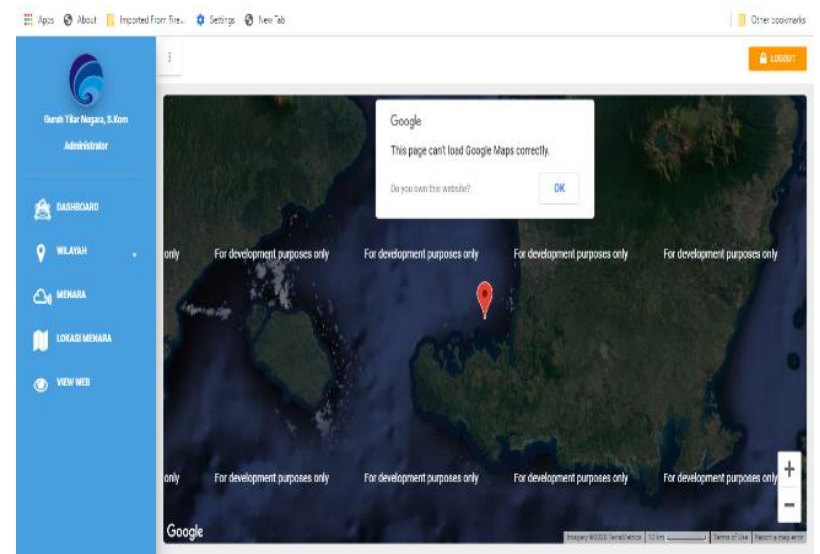

Gambar 10. Halaman Dashboard

Hasil tampilan halaman menu kecamatan merupakan tampilan untuk data wilayah seluruh kecamatan dapat dilihat pada gambar 11 .

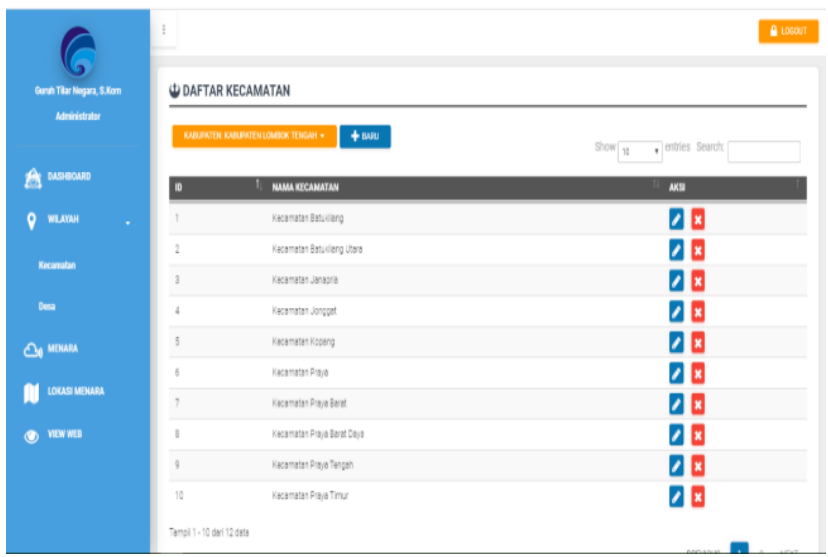

Gambar 11. Halaman Menu Kecamatan 
Vol. 1 No. 1, Feb 2021, hlm. 61 - 70

DOI: https://doi.org/10.33330/.v1i1.1040

Available online at https://jurnal.stmikroyal.ac.id/index.php/jutsi

Hasil tampilan halaman menu desa merupakan tampilan untuk data wilayah seluruh desa dapat dilihat pada gambar 12 .

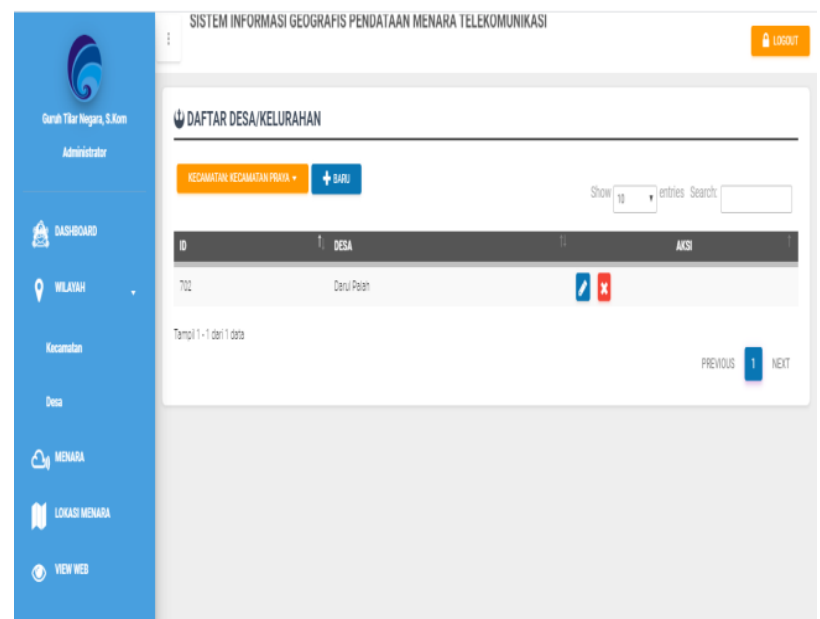

Gambar 12. Halaman Menu Desa

Hasil tampilan halaman menu menara merupakan tampilan yang digunakan untuk menyimpan data menara di system dapat dilihat pada gambar 13.

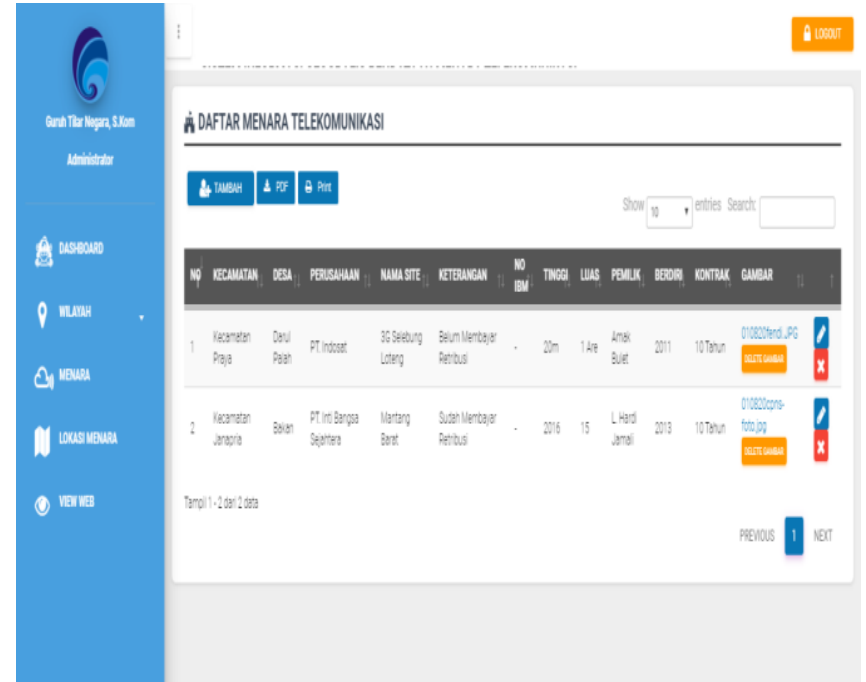

Gambar 13. Halaman Menu Menara

Hasil tampilan halaman menu lokasi menara digunakan untuk menyimpan koordinat menara di system dapat dilihat pada gambar 14 . 
Vol. 1 No. 1, Feb 2021, hlm. 61 - 70

DOI: https://doi.org/10.33330/.v1i1.1040

Available online at https://jurnal.stmikroyal.ac.id/index.php/jutsi

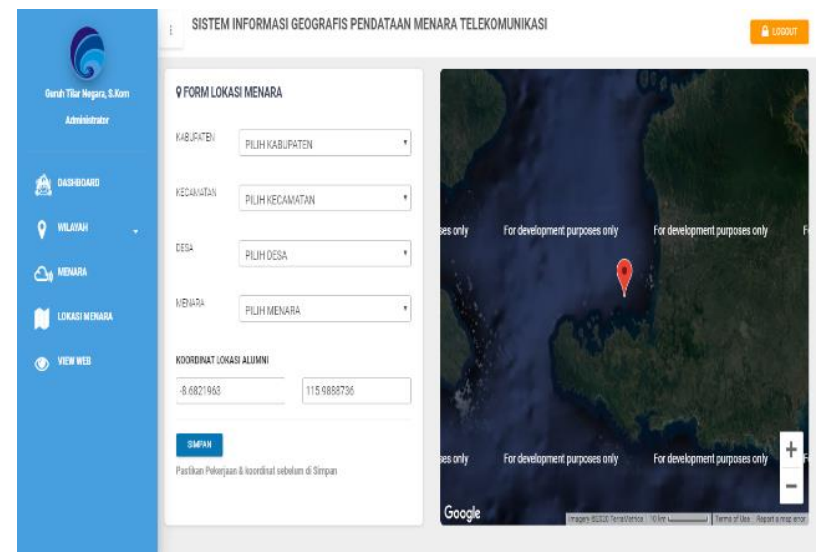

Gambar 14. Halaman Menu Lokasi Menara

Hasil tampilan halaman keterangan menara menampilkan keterangan status menara dapat dilihat pada gambar 15 .

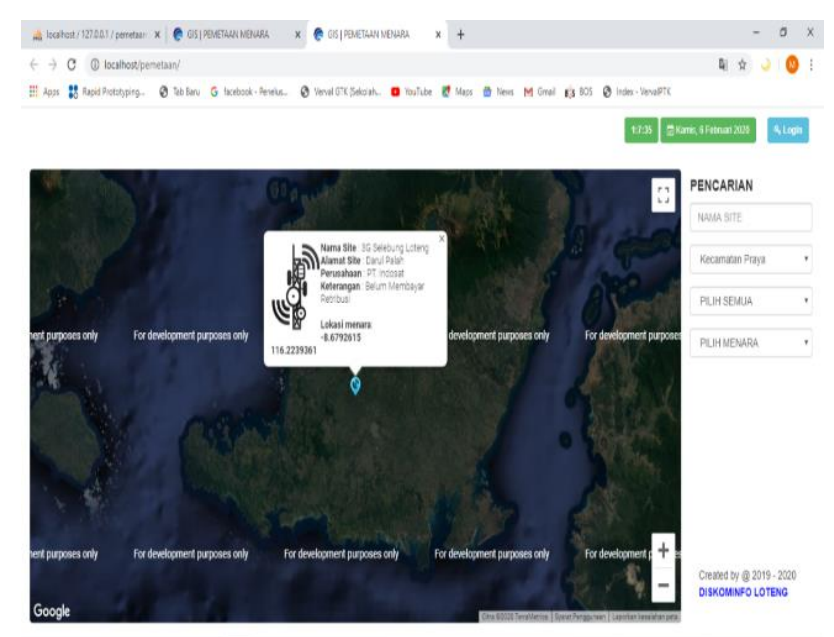

Gambar 15. Halaman Tampilan Keterangan Menara

\section{SIMPULAN}

Dari hasil kesimpulan rancang bangun sistem informasi pemetaan persebaran menara telekomunikasi seluler berbasis web GIS ini adalah suatu proses pemetaan menara telekomunikasi seluler memang perlu adanya dikarenakan banyaknya menara yang tersebar diwilayah kabupaten lombok tengah yaitu 320 menara. Adanya sistem pemetaan menara telekomunikasi seluler tersebut dapat mempercepat memudahkan penyajian informasi mengenai semua menara. Penggunaan software PHP dapat memudahkan user dalam mengakses aplikasi dan MYSQL sebagai database server yang memudahkan untuk mengecek menara. 
Vol. 1 No. 1, Feb 2021, hlm. 61 - 70

DOI: https://doi.org/10.33330/.v1i1.1040

Available online at https://jurnal.stmikroyal.ac.id/index.php/jutsi

\section{DAFTAR PUSTAKA}

[1] R. Mcleod and G. Schell, Sistem Informasi Manajemen. Jakarta: PT Prenhall Indo, 2004.

[2] R. E. Jeffries, "Extreme Programming: A gentle introduction," 2001.

[3] H. F. Muttaqin, "Perancangan Aplikasi Pengelolaan Menara Telekomunikasi ( Bts ) Berbasis Sistem Informasi Geografis," Semin. Nas. Teknol. Inf. dan Multimed., vol. 2, no. 3, pp. 25-30, 2017.

[4] A. A. N. H. Susila, I. N. Piarsa, and P. W. Buana, "Sistem Informasi Geografis Pemetaan Jaringan Pipa PDAM Tirta Mangutama," Merpati, vol. 1, no. 2, pp. 262-270, 2016, doi: 10.24843/JIM.

[5] H. N. Lengkong, A. A. E. Sinsuw, and A. S. . Lumenta, "Perancangan Penunjuk Rute Pada Kendaraan Pribadi Menggunakan Aplikasi Mobile GIS Berbasis Android Yang Terintegrasi Pada Google Maps," E-journal Tek. Elektro dan Komput., vol. 2015, no. 2015, pp. 18-25, 2015. 